\title{
Pengaruh Penggunaan Game Online terhadap Perilaku Remaja dalam Pelaksanaan Ibadah Shalat di Lingkungan Permata Kopo Kabupaten Bandung
}

\author{
Nadhief Muhammad Fauzan*, Bambang Saiful Ma'arif \\ Prodi Komunikasi Penyiaran Islam, Fakultas Dakwah, Universitas Islam \\ Bandung, Indonesia. \\ *nadhief24@gmail.com, bambangmaarif76@gmail.com
}

\begin{abstract}
The use of online games in recent years has continued to increase. Online games are growing along with the development of increasingly sophisticated technology. This study aims to determine the magnitude of the influence of online games on adolescent behavior in the implementation of prayer. This study uses quantitative methods. The data collection techniques used are questionnaires, interviews and documentation. The data analysis technique used is descriptive quantitative including correlation analysis, simple linear regression analysis, coefficient of determination and hypothesis testing. The data were analyzed by descriptive analysis method. The results showed that the use of online games greatly influenced the implementation of youth prayers in the Permata Kopo environment, Bandung Regency. The effect of the use of online games on the implementation of youth prayers is $80.2 \%$. The effect caused is a negative influence. The use of online games makes teenagers not pray at the beginning of time, prioritize playing online games rather than praying at the beginning of time, lazy in performing prayers, not having the awareness to pray due to the use of online games and ignoring kaifiat in praying.
\end{abstract}

Keywords: Online Game, Influence, Implementation of Prayers.

\begin{abstract}
Abstrak. Penggunaan game online dalam beberapa tahun ini terus meningkat. Game online semakin berkembang seiring dengan perkembangan teknologi yang semakin canggih. Penelitian ini bertujuan untuk mengetahui besarnya pengaruh game online terhadap perilaku remaja dalam pelaksanaan ibadah shalat. Penelitian ini menggunakan metode kuantitatif. Adapun teknik pengumpulan data yang digunakan adalah kuisioner, wawancara dan dokumentasi. Teknik analisis data yang digunakan adalah deskriptif kuantitatif meliputi analisis korelasi, analisis regresi linear sederhana, koefisien determinasi dan uji hipotesis. Data dianalisa dengan metode deskriptif analisis. Hasil penelitian menunjukan bahwa penggunaan game online sangat berpengaruh terhadap pelaksanaan ibadah shalat remaja di lingkungan Permata Kopo Kabupaten Bandung. Pengaruh penggunaan game online terhadap pelaksanaan ibadah shalat remaja sebesar $80,2 \%$. Pengaruh yang ditimbulkan adalah pengaruh negatif. Penggunaan game online membuat remaja tidak melaksanakan shalat diawal waktu, lebih mendahulukan bermain game online daripada melaksanakan ibadah shalat di awal waktu, malas dalam melaksanakan ibadah shalat, tidak memiliki kesadaran untuk melaksanakan ibadah shalat akibat penggunaan game online dan menjadikan abai terhadap kaifiat dalam pelaksanakan ibadah shalat.
\end{abstract}

Kata Kunci: Game Online, Pengaruh, Pelaksanaan Ibadah Shalat. 


\section{A. Pendahuluan}

Pengaruh game online telah terlihat nyata dikehidupan para remaja. Game online telah mempengaruhi pemahaman mereka mengenai agama, ketaatan terhadap ajarannya dan rasa cinta terhadapnya, termasuk dalam pelaksanaan ibadah shalat. Perkembangan teknologi di era global sangat pesat. Perkembangan teknologi yang pesat secara tidak langsung memberikan pengaruh besar bagi kehidupan manusia dalam berbagai aspek dan dimensi kehidupan. Teknologi sekarang ini menjadi kebutuhan dasar manusia yang didukung dengan perkembangan ilmu pengetahuan yang pesat. Teknologi yang berkembang secara signifikan dan terus menerus berevolusi hingga kini dan semakin mendunia, membuat sistem komunikasi dan komputer berkembang begitu cepat. Kemajuan teknologi merupakan suatu hal yang tidak bisa dihindari (unavoidable) karena perkembangan teknologi akan terus berjalan seiring dengan kemajuan ilmu pengetahuan. Internet merupakan ikon dari perkembangan teknologi di era global saat ini. Hal ini yang membuat setiap individu diseluruh dunia termasuk Indonesia terus berusaha agar dapat mengikuti setiap perkembangan teknologi yang ada, dengan begitu pengetahuan semakin bertambah dan maju seiring perkembangan zaman. Mulai dari perkantoran hingga ke sekolahsekolah, kini berusaha menggunakan kecanggihan internet untuk melakukan aktivitas seharihari.

Penggunaan internet di Indonesia terus meningkat setiap tahun. Apalagi melihat kondisi saat ini yang mengharuskan seluruh masyarakat Indonesia harus menjaga jarak akibat pandemi covid-19. Pandemi yang berlangsung lebih dari satu tahun belakang ini membuat aktivitas sehari-hari lebih banyak dirumah. Salah satu contoh dampak pandemi ini membuat para pekerja dibatasi untuk pergi ke kantor dan bekerja dari rumah (work from home), pelajar pun hampir seluruhnya diharuskan belajar dari rumah atau online (daring). Pertumbuhan game online masih akan sangat fenomenal di masa mendatang. Berbagai gadget baru dengan aplikasi game online yang canggih pun akan bermunculan. Budaya bermain game online menjadi gaya hidup yang banyak digemari oleh masyarakat terutama generasi muda bahkan remaja, baik di daerah pedesaan atau perkotaan termasuk di lingkungan Permata Kopo Kabupaten Bandung.

Berdasarakan observasi dan wawancara dalam kegiatan pra-penelitian terhadap remaja di lingkungan Permata Kopo Kabupaten Bandung yang gemar bermain game online, mayoritas remaja malas dalam melaksanakan shalat, sering terlambat dalam melaksanakan shalat dan mengabaikan kaifiat dalam pelaksanaan ibadah shalat. adalah:

Berdasarkan latar belakang diatas, dapat diketahui bahwa tujuan dari penelitian ini

1. Untuk mengetahui besarnya pengaruh penggunaan game online terhadap ketepatan waktu dalam melaksanakan ibadah shalat pada remaja di lingkungan Permata Kopo Kabupaten Bandung.

2. Untuk mengetahui besarnya pengaruh penggunaan game online terhadap kesadaran dalam melaksanakan ibadah shalat pada remaja di lingkungan Permata Kopo Kabupaten Bandung.

3. Untuk mengetahui besarnya pengaruh penggunaan game online terhadap kaifiat pelaksanaan ibadah shalat pada remaja di lingkungan Permata Kopo Kabupaten Bandung.

\section{B. Metodologi Penelitian}

Metode penelitian ini adalah deskriptif kuantitatif. Data yang dihimpun pada penelitian ini adalah data kuantitatif yang diolah dengan menggunakan statistik. Penentuan metode penelitian dengan menggunakan metode deskriptif kuantitatif dengan tujuan dapat memberikan suatu gambaran terhadap masalah yang akan diteliti, juga dapat dijadikan sebagai bahan mengungkapkan, menjelaskan, dan menganalisis suatu masalah sehingga dapat menemukan suatu hasil. 
Dalam menentukan sampel, peneliti menggunakan Rumus Slovin. Rumus Slovin adalah sebuah rumus yang digunakan untuk mengukur jumlah sampel minimal jika diketahui ukuran populasi. Berdasarkan perhitungan rumus tersebut, diketahui populasi sebesar 124 sehingga jumlah sampel dalam oenelitian ini adalah 55 sampel dengan teknik sampling menggunakan purposive sampling.

Teknik pengumpulan data yang digunakan adalah kuisioner, wawancara dan dokumentasi. Teknik analisis data yang digunakan adalah deskriptif kuantitatif meliputi analisis korelasi, analisis regresi linear sederhana, koefisien determinasi dan uji hipotesis.

Analisis korelasi bertujuan untuk mengetahui tingkat keeratan hubungan antar variabel yang dinyatakan dengan koefisien korelasi (pearson correlation). Analisis regresi linear sederhana bertujuan untuk mengetahui seberapa besar pengaruh variabel independen (X) terhadap variabel dependen (Y). Regresi digunakan untuk mengukur besarnya pengaruh variabel bebas terhadap variabel terikat dan memprediksi variabel terikat dengan menggunakan variabel bebas. Koefisien determinasi bertujuan untuk mengetahui seberapa besar kemampuan variabel independen $(\mathrm{X})$ dalam menjelaskan variabel dependen $(\mathrm{Y})$. Atau dengan kata lain untuk mengetahui seberapa besar pengaruh Penggunaan Game Online (X) terhadap Pelaksanaan Ibadah Shalat (Y). Uji hipotesis merupakan metode pembuktian untuk mengkonfirmasi atau menolak sebuah opini ataupun asumsi dengan menggunakan data sampel. Pengolahan data dibantu dengan program SPSS (Statistical Package for the Social Sciences) 23 for windows.

\section{Hasil Penelitian dan Pembahasan \\ Gambaran Umum}

Permata Kopo merupakan perumahan yang berada di kawasan Kopo Kabupaten Bandung. Berikut merupakan detail lokasi lingkungan Permata Kopo:

Alamat : Jl. Sukamenak Sayati Margahayu Bandung Jawa Barat Indonesia

Desa : Sayati

Kecamatan : Margahayu

Kabupaten : Bandung

Kodepos : 40228

Wilayah Permata Kopo sangat luas mencakup Desa Sayati hingga Desa Sukamenak. Permata Kopo memiliki 16 RW (Rukun Warga), masing-masing RW memiliki 7 hingga 8 RT (Rukun Tetangga). Maka dari itu peneliti memberikan batasan dalam penelitian ini, yaitu Permata Kopo yang berada di Desa Kelurahan Sayati, Kecamatan Margahayu, Kabupaten Bandung RT 05/ RW 14.

\section{Penggunaan Game Online di Lingkungan Permata Kopo Kabupaten Bandung}

Game online merupakan suatu bentuk permainan yang berbasis elektronik dan visual. Game online dimainkan dengan memanfaatkan media visual elektronik yang melibatkan banyak pemain didalamnya, dimana permain ini membutuhkan jaringan internet. Game online mengajarkan sesuatu yang baru karena adanya frekuensi bermain yang sering. Dengan sering melihat dan bermain game online, maka seseorang akan meniru adegan di dalam game online tersebut. Penggunaan game online secara berlebihan tentu membawa pengaruh yang negatif. Hal ini berpengaruh terhadap perilaku remaja sehingga menyebabkan munculnya bentuk-bentuk gangguan perilaku terutama terhadap dimensi religius. Dalam variabel penggunaan game online, terdapat elemen yang digunakan, antara lain:

\section{Intensitas penggunaan game online}

Intensitas penggunaan game online ini bertujuan untuk mengetahui seberapa senang dan menikmati para remaja dalam menggunakan game online. Berikut merupakan presentase mengenai intensitas penggunaan game online yang telah diolah dan diperoleh dari hasil jawaban kuisioner responden/sampel penelitian:

a. 95\% remaja senang ketika bermain game online

b. $96 \%$ remaja menikmati game online

c. $96 \%$ remaja menyukai game online

JRKPI is licensed under Creative Commons Attribution-

NonCommercial-ShareAlike 4.0 International License. Komunikasi Penyiaran Islam 
d. $92 \%$ remaja gelisah ketika tidak bermain game online

e. $93 \%$ remaja merasa tenang ketika bermain game online

f. $91 \%$ remaja tidak dapat menunda game online

Berdasarkan hasil presentase di atas dapat diketahui bahwa mayoritas remaja menyukai, senang dan menikmati game online.

2. Frekuensi penggunaan game onine

Frekuensi penggunaan game online ini bertujuan untuk mengetahui seberapa sering para remaja menggunakan game online. Berikut merupakan presentase mengenai frekuensi penggunaan game online yang telah diolah dan diperoleh dari sampel penelitian:

a. $91 \%$ remaja bermain game online setiap hari

b. $96 \%$ remaja game online dengan teman setiap hari

c. $96 \%$ remaja bermain game online berulang-kali

d. $74 \%$ remaja tidak bermain game online secukupnya

e. $91 \%$ remaja bermain game lebih dari dua kali (sehari)

f. $91 \%$ remaja langsung bermain game online ketika bangun tidur

Berdasarkan hasil presentase di atas dapat diketahui bahwa mayoritas remaja menggunakan game online berulang kali.

3. Durasi penggunaan game online

Durasi penggunaan game online ini bertujuan untuk mengetahui seberapa lama para remaja dalam menggunakan game online. Berikut merupakan tabel-tabel serta penjelasan mengenai durasi penggunaan game online yang diperoleh dari sampel penelitian:

a. $85 \%$ remaja tidak bermain game online dengan jangka waktu yang sebentar

b. $93 \%$ remaja bermain game online dengan jangka waktu yang lama

c. $92 \%$ remaja game online lebih dari 5 jam

d. $96 \%$ remaja menyadari bahwa penggunaan game online membuat lupa waktu

e. 94\% remaja menghabiskan waktu luang untuk bermain game online

Berdasarkan hasil presentase di atas dapat diketahui bahwa mayoritas remaja menggunakan game online dengan durasi yang panjang.

4. Jenis permainan yang digemari

Jenis permainan yang digemari ini bertujuan untuk menganalisis permainan apa saja yang digemari oleh para remaja. Berikut merupakan tabel-tabel serta penjelasan mengenai frekuensi penggunaan game online yang diperoleh dari sampel penelitian:

a. $98 \%$ remaja bermain Player Unknown Battleground (PUBG)

b. $94 \%$ remaja bermain Mobile Legends

c. $74 \%$ remaja bermain FIFA Mobile

d. $73 \%$ remaja Free Fire

Berdasarkan hasil presentase di atas, jenis permainan game online yang paling digemari oleh mayoritas remaja dalah Player UnkownBattleground (PUBG).

Jika mengacu pada tinjauan teoritis menggunakan Teori Ketergantungan Media, hasilnya terbukti bahwa semakin besar kebutuhan pada media maka akibatnya rasa ketergantungan akan semakin besar/kuat. 


\section{Pengaruh Penggunaan Game Online Terhadap Pelaksanaan Ibadah Shalat}

Hasil penelitian menunjukan bahwa penggunaan game online sangat berpengaruh terhadap pelaksanaan ibadah shalat remaja melalui metode kuantitatif. Hasil pengujian dijelaskan pada tabel I.

Tabel I. Pengaruh Penggunaan Game Online (X) Terhadap Pelaksanaan Ibadah Shalat (Y)

\begin{tabular}{|c|c|c|c|c|c|}
\hline Variabel & $\begin{array}{c}\text { Pearson } \\
\text { Correlation }\end{array}$ & $\mathbf{r}_{\mathbf{s}}$ & Sig. & $\begin{array}{c}\text { Uji } \\
\text { Hipotesis }\end{array}$ & $\begin{array}{c}\text { Koefisien } \\
\text { Regresi }\end{array}$ \\
\hline X dan Y & 0,896 & 0,802 & 0,000 & $\begin{array}{c}\text { Ho } \\
\text { ditolak }\end{array}$ & $-0,855$ \\
\hline
\end{tabular}

Sumber: Data Penelitian yang Sudah Diolah, 2021.

Berdasarkan hasil analisis korelasi (Pearson Correlation) pada tabel diatas, dapat diketahui bahwa besarnya nilai korelasi antara variabel independen (X) yaitu Penggunaan Game Online dengan variabel dependen (Y) yaitu Pelaksanaan Ibadah Shalat adalah 0.896 yang berarti terdapat korelasi yang signifikan antara kedua variabel dengan tingkat korelasi sempurna berdasarkan nilai Pearson Correlation sebesar 0.896. Hasil pengujian koefisien determinasi (rs) sebesar 0,802 yang mengandung pengertian bahwa pengaruh variabel bebas yaitu penggunaan game online $(\mathrm{X})$ terhadap variabel terikat yaitu pelaksanan ibadah shalat (Y) adalah sebesar $80,2 \%$. Hasil pengujian hipotesis, diketahui nilai signifikansi (Sig.) sebesar $0.000<0.05$, sehingga dapat dinyatakan bahwa Ho ditolak dan Ha diterima, yang berarti ada pengaruh Penggunaan Game Online (X) terhadap pelaksanaan ibadah shalat remaja (Y). Koefisien regresi variabel (X) penggunaan game online sebesar -0855 menyatakan bahwa setiap penambahan 1\% nilai Penggunaan Game Online, maka nilai Pelaksanaan Ibadah Shalat bertambah sebesar 0,855 . Koefisien regresi tersebut bernilai negatif, sehingga dapat dikatakan bahwa arah pengaruh variable $\mathrm{X}$ terhadap $\mathrm{Y}$ adalah negatif.

Jika mengacu pada tinjauan teoritis Teori Ketergantungan, terbukti bahwa semakin kuat tingkat penggunaan media maka akan semakin besar pula pengaruh sebuah media terhadap pengguna media tersebut. Pengaruh game online terhadap pelaksanan ibadah shalat meliputi ketepatan waktu, kesadaran dan kaifiat. Pengaruh game online terhadap ketepatan waktu membuat remaja tidak melaksanakan shalat diawal waktu, selain itu remaja lebih mendahulukan bermain game online daripada melaksanakan ibadah shalat di awal waktu. Pengaruh game online terhadap kesadaran dalam pelaksanaan ibadah shalat, membuat remaja malas dalam melaksanakan ibadah shalat, selain itu membuat remaja tidak memiliki kesadaran untuk melaksanakan ibadah shalat ketika sedang bermain game online. Pengaruh game online terhadap kaifiat dalam pelaksanaan ibadah shalat, menjadikan remaja abai terhadap kaifiat dalam melaksanakan ibadah shalat.

\section{Kesimpulan}

Berdasarkan pembahasan dalam penelitian ini, peneliti menyimpulkan beberapa hasil penelitian sebagai berikut:

Pertama, bahwa terdapat pengaruh negatif antara penggunaan game online terhadap ketepatan waktu dalam pelaksanaan ibadah shalat. Penggunaan game online tersebut membuat remaja tidak melaksanakan ibadah shalat di awal waktu, selain itu remaja lebih mendahulukan bermain game oline dibandingkan melaksanakn ibadah shalat terlebih dahulu.

Kedua, bahwa terdapat pengaruh negatif antara penggunaan game online terhadap kesadaran dalam pelaksanaan ibadah shalat. Penggunaan game online tersebut membuat remaja malas untuk melaksanakan ibadah shalat. Selain itu, penggunaan game online juga membuat remaja tidak memiliki kesadaran diri untuk melaksanakan ibadah shalat ketika sedang asyik bermain game online. 
Ketiga, bahwa terdapat pengaruh negatif antara penggunaan game online terhadap kaifiat dalam pelaksanaan ibadah shalat. Penggunaan game online tersebut membuat remaja merasa gelisah ketika shalat karena memikirkan game online dan menjadikan abai terhadap kaifiat ibadah shalat karena memikirkan game online yang belum selesai.

Penelitian ini diharapkan dapat mencapai tujuan dakwah sebagai mahasiswa Fakultas Dakwah. Dakwah bertujuan menciptakan tatanan kehidupan indiidu dan masyarakat yang aman, damai dan sejahtera yang dinaungi oleh kebahagiaan baik jasmani maupun rohani dalam pancaran sinar agama Allah dengan mengharapkan ridhaNya. Suatu tujuan dakwah seyogyanya dicermati dengan baik agar membuahkan keluaran yang terukur.

\section{Acknowledge}

Alhamdulillahirabbil'alamin, puji dan syukur peneliti panjatkan ke Hadhirat Allah SWT atas segala rahmat, karuniaNya dan kasih sayangNya sehingga atas ridhoNya peneliti dapat menyelesaikan penelitian dengan judul "Pengaruh Penggunaan Game Online Terhadap Perilaku Remaja Dalam Pelaksanaan Ibadah Shalat di Lingkungan Permata Kopo Kabupaten Bandung". Shalawat serta salam senantiasa tercurah limpahkan kepada Rasulullah SAW yang senantiasa menjadi sumber inspirasi dan teladan terbaik untuk umat manusia, beserta keluarganya, sahabat dan para pengikut setianya hingga akhir zaman.

Penelitian ini dimaksudkan untuk memenuhi sebagian syarat-syarat guna mencapai gelar Sarjana Sosial (S.Sos) di Universitas Islam Bandung, Fakultas Dakwah, Prodi Komunikasi dan Penyiaran Islam. Penelitian ini diharapkan dapat bermanfaat bukan hanya kepada teoritisi tetapi juga kepada para praktisi yang bisa dijadikan rujukan atau referensi penelitian lainnya. Atas segala pertolonganNya, peneliti dapat menyelesaikan penelitian ini. Namun terselesaikannya penelitian ini semata-mata bukan hanya karena usaha peneliti seorang diri, melainkan dengan bantuan tulus dari berbagai pihak baik secara moril ataupun materil. Maka dari itu, peneliti ingin mengucapkan terimakasih dan penghargaan sebesar-besarnya kepada kedua orang tua, Ibunda Dinar Desfina dan Ayahanda Zein Fithry yang telah mencurahkan kasih sayangnya untuk membesarkan dan mendidik peneliti sampai saat ini, yang juga telah memberikan nasihat, motivasi dan tidak pernah berhenti memberikan segala bentuk dukungan baik secara moril maupun materil serta doa yang selalu dipanjatkan sehingga peneliti mampu menyelesaikan perkuliahan dan selesainya penelitian dengan baik. Kepada adik tercinta, Rifky Muhammad Fachri yang telah menghibur dan selalu menyemangati peneliti ketika dalam keadaan baik maupun tidak baik sehingga pada akhirnya peneliti mampu menyelesaikan Penelitian ini.

Tidak lupa peneliti menyadari bahwa penelitian ini tidak dapat terselesaikan tanpa dukungan dari berbagai pihak baik moril maupun materil. Oleh karena itu, penulis ingin menyampaikan ucapan terima kasih sebagai wujud penghargaan yang paling tulus kepada semua pihak yang telah membantu dalam selesainya penelitian ini. Terima kasih yang sebesarbesarnya peneliti sampaikan kepada:

1. Bapak Dr. H. Komarudin Shaleh, Drs., M.Ag. selaku Dekan Fakultas Dakwah yang telah memberikan ilmunya, pengalamannya yang berharga serta support selama proses perkuliahan hingga selesainya penelitian ini.

2. Ibu Dr. Nia Kurniati Syam, Dra., M.Si., selaku Ketua Prodi Komunikasi Penyiaran Islam yang telah memberikan nasihat, motivasi serta dukungan selama proses perkuliahan hingga selesainya penelitian ini.

3. Bapak Dr. Bambang S. Ma'arif, Drs., M.Si., selaku Dosen Pembimbing I yang telah mendukung secara lahir dan batin, membantu dan senantiasa meluangkan waktunya untuk membimbing penulis dengan sabar, ikhlas dan tanpa lelah disela-sela kesibukannya sehingga penulis termotivasi untuk terus belajar dan memperbaiki selesainya penelitian ini.

4. Bapak Muhammad Fauzi Arif, S.Sos.I., M.I.Kom., selaku Dosen Pembimbing II yang telah meluangkan waktunya untuk membimbing, mengarahkan, memberikan semangat serta dukungan selama proses perkuliahan hingga selesainya penelitian ini. 
5. Ibu Dr. Rodliyah Khuza'i, Dra., M.Ag. selaku Dosen Wali yang telah membimbing selama proses perkuliahan juga memberi semangat kepada penulis dalam menyelesaikan penelitian ini.

6. Bapak Nandang HMZ, Drs., M. Si., selaku Wakil Dekan Fakultas Dakwah Unisba yang juga menjadi pembimbing dalam selesainya laporan Job Training sehingga telah memberikan pengalaman dan pembelajaran selama proses perkuliahan hingga selesainya penelitian ini.

7. Seluruh Dosen Prodi Komunikasi dan Penyiaran Islam, Fakultas Dakwah Unisba yang sudah banyak memberi ilmu yang bermanfaat dan berbagi pengalaman yang sangat luar biasa juga memberi semangat serta motivasi dalam setiap pembelajaran selama kuliah.

8. Keluarga besar peneliti, Ibu Intan Pujatresna, Ibu Noviana, Bapak Fahmi, Bapak Dono, Lukhman Nulhakim, Nisrina Syarifa Fahmi yang telah banyak memberikan dukungan moril serta materil agar dapat menyelesaikan penelitian dengan baik.

9. Keluarga besar mahasiswa Fakultas Dakwah angkatan 2017, khususnya kelas A yang banyak memberi dukungan moril bagi peneliti, baik selama masa perkuliahan berlangsung dan selama proses penelitian.

10. Seluruh staf, karyawan dan sivitas akademika Fakultas Dakwah yang telah memberikan bantuan berupa dukungan, akses serta fasilitas kepada peneliti.

\section{Daftar Pustaka}

[1] Aih, Euis. "Modernisasi Pembelajaran di Perguruan Tinggi Berbasis Teknologi Informasi dan Komunikasi" dalam Jurnal Pendidikan Unsika, Tahun 2016.

[2] Aji, Candra Zebeh. 2012. Berburu Rupiah Lewat Game Online, Yogyakarta: Bouna Books.

[3] Arikunto, Arikunto. 2013. Prosedur Penelitian: Suatu Pendekatan Praktek, Jakarta: Rineka Cipta.

[4] Ayu Rini, 2011. Menanggulangi Kecanduan Game Online Pada Anak, Jakarta: Pustaka Mina.

[5] Defleur, Melvin, dan Sandra Ball-Rokeach. 1982. Theories of Mass Communication. New York: Kongman Inc.

[6] Hakim, Saifudin, 2018, Memanfaatkan Waktu Luang untuk Hal-Hal yang Bermanfaat, dalam https://muslim.or.id/37903-memanfaatkan-waktu-luang-untuk-hal-hal-yangbermanfaat.html.

[7] Henry, Samuel. 2010. Cerdas dengan Game: Panduan Praktis bagi Orangtua dalam Mendampingi Anak Bermain Game, Jakarta: PT Gramedia Pustaka Utama

[8] Kurniawan Wiharsono. 2007, Jaringan Komputer, Yogyakarta: CV. Andi Offset.

[9] Kustiawan, Andri Arif. 2019. Jangan Suka Game Online: Pengaruh Game Online dan Tindak Pencegahan, Magetan: CV. AE Media Grafika.

[10] Maarif, Bambang. S., 2010, Komunikasi Dkwah: Paradigma Untuk Aksi, Bandung: Simbiosa Rekatama Media.

[11] Prawiradilaga, Dewi Salma. 2013. Mozaik Teknologi Pendidikan ELearning, Jakarta: Kencana Prenadema Group.

[12] Sugiyono. 2008. Metode Penelitian Pendidikan: Pendekatan Kuantitatif, Kualitatif dan $R \& D$, Bandung: Alfabeta, Cet. Ke-4. 